\title{
Molecular systematics of the subaerial green algal order Trentepohliales: an assessment based on morphological and molecular data
}

\author{
Juan M. López-Bautista, ${ }^{1}$ Fabio Rindi ${ }^{2}$ and Michael D. Guiry ${ }^{2}$ \\ ${ }^{1}$ Department of Biological Sciences, The University of Alabama, Tuscaloosa, AL 35487-0345, \\ USA \\ ${ }^{2}$ Martin Ryan Institute, National University of Ireland, Galway, Ireland
}

Correspondence

Juan M. López-Bautista

jlopez@bama.ua.edu

\section{INTRODUCTION}

The order Trentepohliales is a group of subaerial green algae widespread in regions with humid climates and growing on rocks, buildings, tree bark, leaves, stems and fruits (Printz, 1939; Chapman, 1984; Ettl \& Gärtner, 1995). These algae consist of branched uniseriate filaments that may be either free or coalescing to produce pseudoparenchymatous masses or monostromatic discs, and possess specialized zoosporangia with a morphology unique among the green algae (Chapman, 1984; López-Bautista et al., 2002). Although present in temperate regions, they are most abundant and diverse in the tropics and, due to the production of carotenoid pigments, they form yellow, orange or red coatings on the surfaces on which they occur. Some species are endophytic or parasitic, whereas others grow in close association with fungi, forming lichens (Uyenco, 1965; Chapman \& Good, 1983; Chapman \& Waters, 2001). As currently circumscribed, the Trentepohliales includes six genera. Trentepohlia Martius 1817, which includes branched filamentous species, was the first genus described and accounts for the largest number of species (about 35).

The GenBank/EMBL/DDBJ accession numbers for the new 18S rRNA gene sequences determined in this study are DQ399583-DO399595, as listed in Table 1.
Physolinum was described by Printz (1921) as a monospecific genus based on a species previously included in Trentepohlia (Trentepohlia monilia De Wildeman). However, the main character used for its separation (reproduction by aplanospores) is dubious and the validity of this genus is controversial. Printzina includes nine species, transferred from Trentepohlia into an independent genus by Thompson \& Wujek (1992) on the basis of differences in the vegetative habit and shape of the zoosporangia. Species of Phycopeltis Millardet 1870 occur epiphytically on leaves (less frequently on stems) of higher plants and consist of prostrate, branched filaments, either free or (most commonly) coalescing to form a monostromatic disc; as currently circumscribed, this genus includes 25 species. Cephaleuros Kunze ex Fries 1832 comprises 15 species consisting of branched filaments, free or coalescing to form irregular discs that grow below the cuticle and the epidermis of the leaves of higher plants. Finally, Stomatochroon Palm 1934 consists of filaments growing endophytically in the substomatal chambers and through intercellular spaces of plant leaves; sporangial branches are the only parts of the thallus that emerge from the host. This genus currently includes four species.

Despite their relatively simple morphology, the Trentepohliales are a taxonomically difficult group. It is well known 
that the morphology of many species is subject to great variation (Hariot, 1889c; Printz, 1939; Rindi \& Guiry, 2002a), linked to environmental factors. The validity of several morphological characters used for separation at the species and genus level is dubious and, especially in Trentepohlia and Printzina, several important morphometric characters show considerable overlap between different species. The current system of classification of this group is based entirely on morphological features and identification at the species and genus level is largely based on the monographs of Printz $(1939,1964)$ and, for Cephaleuros, Phycopeltis and Stomatochroon, of Thompson \& Wujek (1997). To date, it is impossible to assess which morphological characters used for separation of species and genera are phylogenetically significant. In this study, we provide the first general assessment of the taxonomy of the Trentepohliales at the genus level based on molecular data. Sequences of a marker widely used for phylogenetic inference in algae, the nuclear small subunit rRNA gene (18S rDNA), were used to obtain a phylogenetic arrangement that was compared with traditional classification schemes based on morphology.

\section{METHODS}

Twenty-two isolates, obtained either from material collected and identified directly by the authors or from culture collections, were used for the study. Species investigated, collection data, GenBank accession numbers and additional information are reported in Table 1. Vouched specimens of the collections made by the authors are deposited in the Phycological Herbarium, National University of Ireland, Galway (GALW), and in the Herbarium of the University of Alabama (UNA). Samples collected during field trips were preserved in silica gel. DNA extraction protocols have been described previously (López-Bautista \& Chapman, 2003). PCR amplification and sequencing of the $18 \mathrm{~S}$ rDNA was performed using primers designed for both green algae and plants (Hamby et al., 1988). PCR and cycle sequencing conditions were as described by López-Bautista \& Chapman (2003). Samples were sequenced in an ABI 3100 automated genetic analyser. Sequence data were edited and aligned using Sequencher 4.5 (Gene Codes Corporation). The alignments used for the analyses are available from the authors on request. Edited sequences were adjusted manually using MacClade 4.06 (Maddison \& Maddison, 2000). Phylogenetic reconstructions based on the $18 \mathrm{~S}$ rDNA database were performed using PAUP* 4.0 (Swofford, 2000) and MRBAYES 3.0 (Huelsenbeck et al., 2001). All analyses were performed using a Dual G5 Macintosh computer. A total of 22 trentepohlialean taxa was used to build the data matrix with two cladophoralean taxa as the outgroup. Computer analyses were implemented with the distance, parsimony, maximum-likelihood and Bayesian inference methods for phylogenetic reconstruction. Bootstrap analyses (Felsenstein, 1985) assessed the support of nodes with 1000 replications for distance, maximum-parsimony and maximum-likelihood analyses. Estimation of the posterior probabilities for maximum-likelihood topologies was performed using MRBAYES 3.0. One million generations were run under Bayesian analysis, trees sampled every 100 and the earliest 4000 trees (burnt) were discarded. Computation of a consensus tree was estimated using PAUP* 4.0. Model parameters used during the inference methods to reconstruct phylogenies were estimated with MODELTEST 3.7 (Posada \& Crandall, 1998). Distance and maximum-parsimony analyses were carried out with PAUP* 4.0. Maximum-parsimony analyses were executed with the heuristic search option with a branch-swapping algorithm (tree bisection-reconnection) and random sequence addition of 1000 replicates. The resulting phylogenetic trees were edited using Adobe Illustrator CS2.

\section{RESULTS AND DISCUSSION}

Despite the relatively limited number of species included in the analyses, the results obtained in this study provide important insights into the phylogeny of the Trentepohliales at the genus and species level. The inclusion of Stomatochroon and a wider set of species (especially of Phycopeltis and Cephaleuros) will be necessary for a detailed reassessment; the sequences presently available, however, are sufficient to show that in many cases the morphological criteria traditionally used for the circumscription of genera and species of Trentepohliales do not match phylogenetic patterns.

Four main lineages are present in the $18 \mathrm{~S}$ rDNA phylogeny: (i) a basal clade including isolates of species currently assigned to Trentepohlia and Phycopeltis, (ii) a small group represented by the two isolates of Trentepohlia aurea (which should be considered the authentic genus Trentepohlia, since T. aurea is the type species of the genus), (iii) a divergent lineage including species of Trentepohlia, Printzina and Physolinum and (iv) a derived monophyletic clade in which all samples of Cephaleuros are grouped (Fig. 1). The support for individual groups of isolates is in some cases relatively weak, and the inclusion of a larger number of species is expected to resolve relationships and provide better support; however, the main lineages are relatively well supported and the inclusion of further sequences is unlikely to change their relative arrangement. On the basis of our results, Cephaleuros forms a well-defined monophyletic group, representing a more advanced clade. Conversely, Trentepohlia is polyphyletic and the other genera included in the analyses do not represent separate lineages, suggesting the possibility that a major rearrangement at the genus level may be necessary in the future.

The taxonomic criteria on which the genus Trentepohlia has been traditionally based will have to be reassessed and a much narrower circumscription of the genus, with the erection of several new genera, might eventually prove to be an appropriate solution. In the $18 \mathrm{~S}$ rDNA phylogeny the two samples of T. aurea, the type species of Trentepohlia, form a moderately supported clade, separated from all other samples sequenced. Sequences from a larger number of species of Trentepohlia will be necessary to assess the taxonomic level at which a separation between $T$. aurea and other species currently attributed to the genus can be proposed. In any case, our results show that species for which the attribution to Trentepohlia is beyond any doubt from a morphological point of view (Trentepohlia abietina, T. annulata, T. arborum and T. iolithus) are phylogenetically closer to members of Cephaleuros, Phycopeltis and Printzina than to T. aurea. Our analyses do not provide support for the validity of Physolinum or Printzina and it is likely that these genera will have to be reduced to synonyms of other 
Table 1. Strains used for sequencing

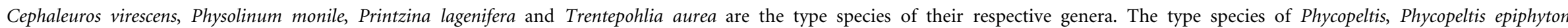
Millardet, was not included.

\begin{tabular}{|c|c|c|c|}
\hline Species & Origin & $\begin{array}{c}\text { GenBank } \\
\text { accession no. }\end{array}$ & Notes \\
\hline Cephaleuros parasiticus Karsten & $\begin{array}{l}\text { Leaves of Magnolia sp., LSU campus, Baton Rouge, LA, USA; } \\
\text { culture LSU BR52 }\end{array}$ & AY052563 & López-Bautista \& Chapman (2003) \\
\hline Cephaleuros parasiticus Karsten & Culture UTEX & DQ399583 & \\
\hline Cephaleuros virescens Kunze & Culture LSU BR50 & AY052564 & López-Bautista \& Chapman (2003) \\
\hline Cephaleuros virescens Kunze & Navaho isolate, Louisiana, USA & DQ399584 & \\
\hline Cephaleuros virescens Kunze & South Africa; culture SAG 25.83 (isolate 414) & DQ399595 & \\
\hline Cephaleuros virescens Kunze & South Africa; culture SAG 28.93 (isolate 415) & AY220984 & \\
\hline Cephaleuros virescens Kunze & South Africa; culture SAG 119.80 (isolate 418) & DQ399594 & \\
\hline Cephaleuros virescens Kunze & Taiwan; culture SAG 42.85 (isolate 416 ) & DQ399585 & \\
\hline Phycopeltis arundinacea (Montagne) De Toni & On leaves of ivy; Moycullen, Co. Galway, Ireland & AY052570 & Details of morphology in Rindi \& Guiry (2002b) \\
\hline Physolinum monile (De Wildeman) Printz & USA (exact location unknown); LSU culture collection & AY052565 & López-Bautista \& Chapman (2003) \\
\hline $\begin{array}{l}\text { Printzina lagenifera (Hildebrandt) Thompson \& } \\
\text { Wujek }\end{array}$ & Asbestos wall; NUI, Galway campus, Galway City, Ireland & DQ399586 & Details of morphology in Rindi \& Guiry (2002a) \\
\hline Trentepohlia abietina (Flotow) Hansgirg & Bark of cherry tree; NUI, Galway campus, Galway City, Ireland & DQ399587 & Details of morphology in Rindi \& Guiry (2002a) \\
\hline Trentepohlia annulata Brand & Czech Republic; culture SAG 20.94 & DQ399588 & \\
\hline Trentepohlia arborum (C. Agardh) Hariot & Greenhouse, University of São Paulo campus, São Paulo, Brazil & AY052566 & López-Bautista \& Chapman (2003) \\
\hline Trentepohlia arborum (C. Agardh) Hariot & Waipio Valley, Hawaii, USA & DQ399589 & Details of morphology in Rindi et al. (2005) \\
\hline Trentepohlia aurea (Linnaeus) Martius & Aberystwyth, Wales, UK; culture UTEX LB429 & AY052567 & López-Bautista \& Chapman (2003) \\
\hline Trentepohlia aurea (Linnaeus) Martius & Concrete wall; Claddagh Quay, Galway City, Ireland & DQ399590 & Details of morphology in Rindi \& Guiry (2002a) \\
\hline Trentepohlia iolithus (Linnaeus) Wallroth & Concrete wall; Dyke Road, Galway City, Ireland & AY220983 & Details of morphology in Rindi \& Guiry (2002a) \\
\hline Trentepohlia umbrina (Kützing) Bornet & Limestone wall; NUI, Galway campus, Galway City, Ireland & DQ399591 & Details of morphology in Rindi \& Guiry (2002a) \\
\hline Trentepohlia sp. & Bark of tree; near Knysna, South Africa; culture 563 & DQ399592 & \\
\hline Trentepohlia sp. & Phycobiont from lichen, Massachusetts, USA; culture UTEX 1227 & AY052569 & López-Bautista \& Chapman (2003) \\
\hline Trentepohlia sp. & Phycobiont from lichen, Germany; culture SAG 117.80 & DQ399593 & \\
\hline
\end{tabular}




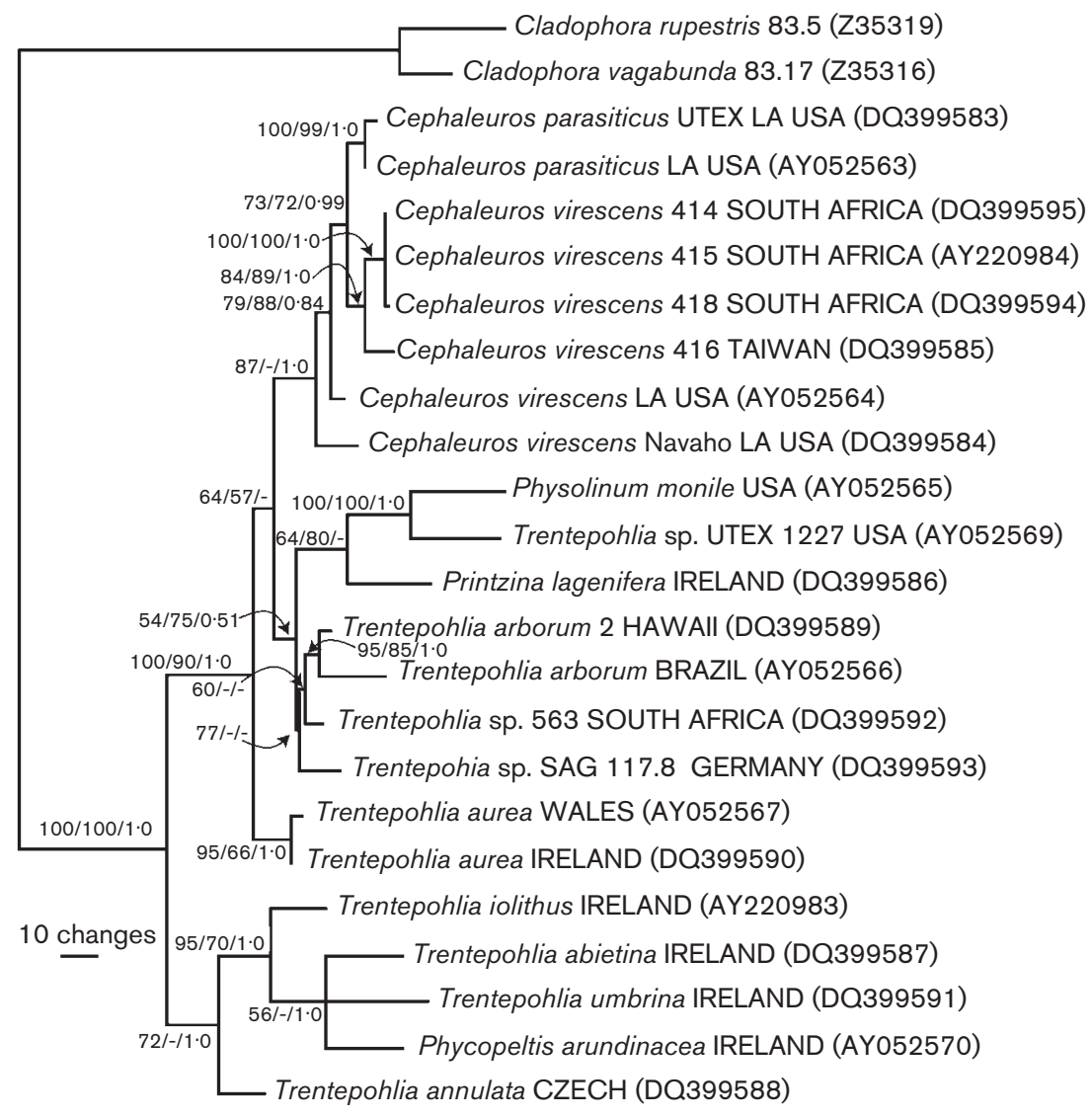

Fig. 1. Maximum-likelihood tree resulting from analysis of $18 \mathrm{~S}$ rDNA sequences $(-\ln L=5975.5283)$ for 22 trentepohlialean taxa (1810 characters). Support values are shown on the branches (maximum likelihood/ maximum parsimony/Bayesian). genera (or, in the case of Printzina, the circumscription at the species level will need reassessment), which is, however, not a surprising conclusion. Physolinum was erected by Printz (1921) as a monospecific genus for T. monilia, described by De Wildeman (1891) for material occurring on tree bark in Chile. Printz $(1921,1939)$ separated this species from Trentepohlia on the basis of differences in some vegetative (cell division by budding of the cell wall, no distinction between main axes and branches and pronounced constriction between adjacent cells) and reproductive (reproduction by aplanospores) characters. However, the vegetative features typical of Physolinum occur with some degree of variation in several species of Trentepohlia, and more recent reports of $T$. monilia have noted the presence of zoosporangia and gametangia in this species (Flint, 1959; Chowdary, 1963; Sarma, 1986). There are therefore no morphological characters that may reliably separate Physolinum from Trentepohlia and, with only few exceptions (e.g. Sarma, 1986; Davis \& Rands, 1993), the two genera have not been separated in the recent literature.

Printzina was proposed by Thompson \& Wujek (1992) as a new genus for nine species previously belonging to Trentepohlia. The shape of the sporangia, the arrangement of the sporangiate laterals, the extensive development of the prostrate parts of the thallus and occurrence in shaded habitats were considered by Thompson \& Wujek (1992) as the key characters that separate Printzina from Trentepohlia. However, an examination of reliable descriptions of the morphology of many species shows that, for these characters, there is a large overlap with Trentepohlia; it is also peculiar that, for a genus in which the prostrate system is well developed, Thompson \& Wujek (1992) designated the generitype Printzina lagenifera, a species in which there is not a clear distinction between erect and prostrate parts (Printz, 1939; Nakano \& Handa, 1984; Rindi \& Guiry, 2002a). The only feature that separates the two genera conclusively is the shape of the sporangia (globular to reniform in Printzina, ovoid in Trentepohlia), which seems a quite tenuous character to justify separation at the genus level.

The position of Phycopeltis in the 18S rDNA tree is one of the most surprising results obtained in this study. Although some species of Trentepohlia and Printzina show an extensive development of prostrate filaments and appear intermediate between Phycopeltis and typical forms of Trentepohlia, the genus Phycopeltis is well characterized by its epiphytic habit, usually consisting of monostromatic, disc-shaped or branched thalli (Printz, 1939; López-Bautista et al., 2002). Thompson \& Wujek (1997) reassessed the circumscription of this genus, highlighting the importance of the position of the ostiole in the zoosporangium (opposite to the end of attachment) as a key character. No 
attention had been paid to this feature in the previous literature and the exact position of the ostiole seems to be largely unknown in many species of Trentepohlia; it is therefore difficult to assess its taxonomic importance. The specimens of Phycopeltis arundinacea sequenced in this study showed the morphology typical of the genus (see details in Rindi \& Guiry, 2002b), and the position of the ostiole was in agreement with the scheme of Thompson \& Wujek (1997). In the analysis, Phycopeltis arundinacea forms a clade with Trentepohlia umbrina and T. abietina. The population of T. umbrina used in this study was collected from carved limestone blocks and did not produce any zoosporangia, which made it impossible to observe the position of the ostiole (Rindi \& Guiry, 2002a, 2003). Thompson \& Wujek (1997), however, reported it as opposite to the end of attachment and, for this reason, transferred the species to Phycopeltis (although this transfer has not been accepted unanimously in the recent literature). For T. abietina, zoosporangia seem to be exceedingly rare in European isolates, whereas reports for tropical populations are not uncommon (De Wildeman, 1891, 1900; Cribb, 1958, 1970). No zoosporangia occurred in the population of T. abietina sequenced in this study (see Rindi \& Guiry, 2002a), but we have recently examined zoosporangial specimens from Hawaii in which the ostiole was clearly opposite to the end of attachment (Rindi et al., 2005). Our results therefore provide some evidence that this feature may be a good phylogenetic marker; it is obvious, however, that a larger number of sequences and a careful assessment of this character in all species currently referred to Trentepohlia, Printzina and Phycopeltis are necessary to confirm this hypothesis.

Several important indications about relationships at the species level are also emerging from our data. Cephaleuros virescens Kunze, the generitype of Cephaleuros, is generally considered to have a worldwide distribution in tropical and subtropical regions, where it has been recorded on members of more than 40 families of vascular plants (MarcheMarchad, 1981; Thompson \& Wujek, 1997; Brooks, 2004). The strains of $C$. virescens sequenced in this study do not represent a monophyletic group; the strains from South Africa and Taiwan are more closely related to Cephaleuros parasiticus than to other strains from the USA attributed to the same species. This suggests that the circumscription of $C$. virescens should be carefully reconsidered and that the morphological characters used to separate this species from similar taxa should be reassessed. As currently circumscribed, C. virescens probably represents a complex of morphologically similar entities and it is possible that the distribution of this alga is much more restricted than present records suggest. Since Surinam is the type locality of C. virescens (Hariot, 1889a), the actual distribution of this species might be restricted to tropical South and Central America.

The taxonomic relationships between T. abietina and $T$. aurea have long been debated. It has been generally recognized that $T$. abietina and thin forms of $T$. aurea are very similar and may be impossible to separate on morphological grounds (Hariot, 1889b; Printz, 1921, 1939, 1964; John, 2002). The two species are usually distinguished on the basis of characters that may show a considerable degree of overlap, such as differences in the width of filaments (6-10 $\mu \mathrm{m}$ in T. abietina, mostly $10-20 \mu \mathrm{m}$ in T. aurea; Printz, 1939, 1964), texture (more rigid in T. aurea; Hariot, $1889 \mathrm{~b}$ ) and arrangement of the zoosporangia (less regular in T. abietina; Hariot, 1889b). It is therefore interesting that, in our analyses, T. aurea and T. abietina occur in different lineages, indicating a marked separation. This suggests that a reconsideration of the morphological features used for the identification of these species (and presumably other species of Trentepohlia) will be necessary; new, phylogenetically reliable characters that have not been used in the past will have to be considered.

Although the number of taxa identified at the species level is not yet large, our analyses provide several important indications about the morphological and ecological characters that can be considered significant from a phylogenetic point of view. There is evidence that the evolution of a subcuticular habit and a heteromorphic life history, typical of Cephaleuros, are derived characters that represent good phylogenetic markers. The occurrence of zoosporangia in clusters located at the top of the sporangiate laterals is typical of Cephaleuros, Stomatochroon and a few species of Trentepohlia, in particular T. arborum. In our $18 \mathrm{~S}$ rDNA phylogeny, this character is absent in the two basal lineages; it occurs in Cephaleuros, which represents the most advanced lineage, and in T. arborum, which is placed in the other derived lineage. There is therefore evidence that this character is derived and may be a good phylogenetic marker; the inclusion of Stomatochroon and other species of Trentepohlia will provide further insights in this regard. It is also evident that several morphological features that are useful for identification at the species level are not phylogenetically relevant. The shape (cylindrical versus globular/ elliptical) and size of cells are generally used as the main characters for the separation of species or groups of species in Trentepohlia. In our analyses, however, species with globular cells and relatively large cell diameters ( $T$. iolithus, T. umbrina) occur mixed with species with cylindrical cells and smaller cell diameter ( $T$. abietina, T. annulata). The habit of the thallus also seems to be a character of very limited value, since forms with well-developed erect axes and limited prostrate parts (e.g. T. abietina) are closely related to forms producing irregular masses without differentiation between erect and prostrate parts (T. umbrina) and forms consisting primarily of monostromatic coalescent thalli (Phycopeltis arundinacea). The type of substratum colonized is considered in some cases an important criterion to separate morphologically close species (e.g. epilithic T. iolithus and corticolous Trentepohlia odorata; Hariot, 1889c; Printz, 1939), but species occurring on different substrata do not form separate clades in our $18 \mathrm{~S}$ rDNA phylogeny. For example, the epiphytic Phycopeltis 
arundinacea and T. abietina occur together with T. iolithus and the epilithic strain of T. umbrina sequenced here. This indicates that this character also has no phylogenetic value.

As a general conclusion, our results represent the first general assessment of the systematics and phylogeny of the Trentepohliales at the species and genus level. The conclusions obtained provide important indications of the phylogenetic relevance of the morphological characters used for the circumscription of species and genera and represent a base of knowledge of fundamental value for future taxonomic assessments of this order. Our preliminary analyses challenge the traditional systematics of the order Trentepohliales, and a re-evaluation is called for of taxonomic characters that are more evolutionarily significant. We are currently integrating a more comprehensive investigation, including more $18 \mathrm{~S}$ rDNA and $r b c L$ sequences (López-Bautista et al., 2003a), as well as the internal transcribed spacer regions of the rRNA genes (ITS and $5 \cdot 8 \mathrm{~S}$ rRNA gene) and phragmoplastin (López-Bautista et al., $2003 \mathrm{~b}$ ), in order to understand the evolution and systematics of this enigmatic group of green algae.

\section{ACKNOWLEDGEMENTS}

We are very grateful to Alison Sherwood, Suzanne Fredericq, Gordon Holcomb and Paul Broady for supplying samples for this study. F. R. acknowledges financial support from the Higher Education Authority, Ireland, under the PRTLI Programme for the Environmental Change Institute, National University of Ireland, Galway. This research was supported by a Research Advisory Committee Grant from The University of Alabama and by NSF/DEB-0542924 to J. M. L.-B.

\section{REFERENCES}

Brooks, F. E. (2004). Plant-parasitic algae (Chlorophyta: Trentepohliales) in American Samoa. Pacific Sci 58, 419-428.

Chapman, R. L. (1984). An assessment of the current state of our knowledge of the Trentepohliaceae. In Systematics of the Green Algae, pp. 233-250. Edited by D. E. G. Irvine \& D. M. John. London: Academic Press.

Chapman, R. L. \& Good, B. H. (1983). Subaerial symbiotic green algae: interactions with vascular plant hosts. In Algal Symbiosis: a Continuum of Interaction Strategies, pp. 173-203. Edited by L. J. Goff. Cambridge: Cambridge University Press.

Chapman, R. L. \& Waters, D. A. (2001). Lichenization of the Trentepohliales - complex algae and odd relationships. In Symbiosis, pp. 359-371. Edited by J. Seckbach. Dordrecht: Kluwer Academic.

Chowdary, Y. B. K. (1963). On the cytology and systematic position of Physolinum monilia Printz. Nucleus 6, 43-48.

Cribb, A. B. (1958). The genus Trentepohlia in South-Eastern Queensland. Univ Queensl Pap Dept Bot 3, 193-201.

Cribb, A. B. (1970). A revision of some species of Trentepohlia especially from Queensland. Proc R Soc Queensl 82, 17-34.

Davis, J. S. \& Rands, D. G. (1993). Observations on lichenized and free-living Physolinum (Chlorophyta, Trentepohliaceae). J Phycol 29, 819-825.

De Wildeman, E. (1891). Les Trentepohlia des Indes Neerlandaises. Ann Jard Bot Buitenzorg 9, 127-142 (in French).
De Wildeman, E. (1900). Les Algues de La Flore de Buitenzorg. Leiden: E. G. Brill (in French).

Ettl, H. \& Gärtner, G. (1995). Syllabus der Boden-, Luft- und Flechtenalgen. Stuttgart, Jena \& New York: Gustav Fischer (in German). Felsenstein, J. (1985). Confidence limits on phylogenies: an approach using the bootstrap. Evolution 39, 783-791.

Flint, E. A. (1959). The occurrence of zoospores in Physolinum Printz. New Phytol 58, 267-270.

John, D. M. (2002). Order Trentepohliales. In The Freshwater Algal Flora of the British Isles, pp. 475-479. Edited by D. M. John, B. A. Whitton \& A. J. Brook. Cambridge: Cambridge University Press.

Hamby, R. K., Sims, L., Issel, L. \& Zimmer, E. (1988). Direct ribosomal RNA sequencing: optimization of extraction and sequencing methods for work with higher plants. Plant Mol Biol Rep 6, 175-192.

Hariot, M. P. (1889a). Note sur le genre Cephaleuros. J Bot 3, 284-288 (in French).

Hariot, M. P. (1889b). Notes sur le genre Trentepohlia Martius. J Bot 3, 378-388 (in French).

Hariot, M. P. (1889c). Notes sur le genre Trentepohlia Martius. J Bot 3, 393-405 (in French).

Huelsenbeck, J. P., Ronquist, F., Nielsen, R. \& Bollback, J. P. (2001). Bayesian inference of phylogeny and its impact on evolutionary biology. Science 294, 2310-2314.

López-Bautista, J. M. \& Chapman, R. L. (2003). Phylogenetic affinities of the Trentepohliales inferred from small-subunit rDNA. Int J Syst Evol Microbiol 53, 2099-2106.

López-Bautista, J. M., Waters, D. A. \& Chapman, R. L. (2002). The Trentepohliales revisited. Constancea 83. http://ucjeps.berkeley.edu/ constancea/83/lopez_etal/trentepohliales.html

López-Bautista, J. M., Rindi, F., Guiry, M. D., Broady, P., Brooks, F. \& Chapman, R. L. (2003a). Evolutionary relationships in the family Trentepohliaceae (Chlorophyta: Ulvophyceae). J Phycol 39, 37.

López-Bautista, J. M., Waters, D. A. \& Chapman, R. L. (2003b). Phragmoplastin, green algae and the evolution of cytokinesis. Int J Syst Evol Microbiol 53, 1715-1718.

Maddison, W. \& Maddison, D. (2000). MacClade 4: analysis of phylogeny and character evolution, version 4. Sunderland, MA: Sinauer Associates.

Marche-Marchad, J. (1981). Quelques données écologiques sur Cephaleuros virescens Kunze et les lichens dont il est la gonidie. Cryptogam Algol 2, 289-301 (in French).

Nakano, T. \& Handa, S. (1984). Observations on Trentepohlia lagenifera (Hild.) Wille. (Chlorophyceae, Trentepohliaceae). Jpn J Phycol 32, 354-363.

Posada, D. \& Crandall, K. A. (1998). MODELTEST: testing the model of DNA substitution. Bioinformatics 14, 817-818.

Printz, H. (1921). Subaerial algae from South Africa. K Nor Vidensk Selsk Skr 1, 3-41.

Printz, H. (1939). Vorarbeiten zu einer Monographie der Trentepohliaceen. Nytt Mag Naturvidensk 80, 137-210 (in German).

Printz, H. (1964). Die Chaetophoralen der Binnengewässer. Eine systematische übersicht. Hydrobiologia 24, 1-376 (in German).

Rindi, F. \& Guiry, M. D. (2002a). Diversity, life history and ecology of Trentepohlia and Printzina (Trentepohliales, Chlorophyta) in urban habitats in Western Ireland. J Phycol 38, 39-54.

Rindi, F. \& Guiry, M. D. (2002b). The genus Phycopeltis (Trentepohliaceae, Chlorophycota) in Ireland: a taxonomic and distributional reassessment. Phycologia 41, 421-431.

Rindi, F. \& Guiry, M. D. (2003). Composition and distribution of subaerial algal assemblages in Galway City, western Ireland. Cryptogam Algol 24, 245-267. 
Rindi, F., Sherwood, A. R. \& Guiry, M. D. (2005). Taxonomy and distribution of Trentepohlia and Printzina (Trentepohliales, Chlorophyta) in the Hawaiian Islands. Phycologia $\mathbf{4 4}$ 270-284.

Sarma, P. (1986). The Freshwater Chaetophorales of New Zealand. Nova Hedwigia Beihefte, vol. 58. Berlin: J. Cramer.

Swofford, D. L. (2000). PAUP* - phylogenetic analysis using parsimony, version 4. Sunderland, MA: Sinauer Associates.
Thompson, R. H. \& Wujek, D. E. (1992). Printzina gen. nov. (Trentepohliaceae), including a description of a new species. J Phycol 28, 232-237.

Thompson, R. H. \& Wujek, D. E. (1997). Trentepohliales: Cephaleuros, Phycopeltis, and Stomatochroon. Morphology, Taxonomy, and Ecology. Enfield, NH: Science Publishers.

Uyenco, F. R. (1965). Studies on some lichenized Trentepohlia associated in lichen thalli with Coenogonium. Trans Am Microsc Soc 84, 1-14. 